\title{
EFEK LARVISIDAL EKSTRAK ETANOL DAUN KEMANGI (Ocimumsanctum Linn) TERHADAP LARVA INSTAR III Culexquinquefasciatus
}

\author{
Wijayani LA, ${ }^{1}$ Isti'anah $\mathbf{S}^{2}$ \\ ${ }^{1}$ Mahasiswa Fakultas Kedokteran Universitas Islam Indonesia \\ ${ }^{2}$ Departemen Parasitologi Fakultas Kedokteran Universitas Islam Indonesia
}

\begin{abstract}
Filariasis carried by mosquito Culex quinquefasciatus. Filariasis cause elephantiasis sequelae that often lower the sufferers productivity. Eradication of the disease is difficult, then, an attempt to do is to control the vector. The other way is to use insecticide vector control plant. Basil (Ocimum sanctum Linn) which contain flavonoids, saponins, and eugenol has been shown in the laboratory have larvicidal effect. This study aimed to determine the larvicidal effects from Ethanol extract $96 \%$ of basilleaf (Ocimum sanctum Linn) against third instar larvae of Culex quinquefasciatus. This is an laboratory experimental methods with Post test only control group design. The Ethanol extract of basil leaf (Ocimum sanctum Linn) diluted to a concentration of 5000 ppm, 4500 ppm, $4000 \mathrm{ppm}, 3500 \mathrm{ppm}, 3000 \mathrm{ppm}, 2000 \mathrm{ppm}, 1500 \mathrm{ppm}, 1000 \mathrm{ppm}$. The experiments were repeated three times. Each experiment included a control ie Tween 20 of $0.25 \%$ in distilled water. Statistical analysis was performed with Kruskal-Walls test and probit analysis to determine LC50 and LC90. In the analysis result of Kruskal Walls (CI: 95\%) it obtained the results that each test group had a significant difference $(p=0,005)$ in mortality of third instar larvae of Culex quinquefasciatus. The results of probit analysis showed that the ethanol extract of basil leaf give the concentration LC50 and LC90 2281.931 ppm and 5016.314 ppm. Ethanol extract $96 \%$ of basilleaf (Ocimum sanctum Linn) has an larvicidal effect on third instar larvae of Culex quinquefasciatus.
\end{abstract}

Keywords: Culex quinquefasciatus - larvicidal - ethanol extract - Basilleaf (Ocimum sanctum Linn).

\section{PENDAHULUAN}

Nyamuk adalah serangga yang dapat berperan sebagai vektor penyakit pada manusia (El Hag et al., 1099). Nyamuk Culex quinque fasciatus dapat menjadi vektor dari Wuchereria bancrofti, Brugia sp. Parasit yang hidup di dalam tubuh nyamuk ini dapat menyebabkan penyakit filariasis. Penyakit filariasis memiliki manifestasi klinis berupa gambaran elefantiasis yang dapat menimbulkan kecacatan pada penderita (Zulkoni, 2010).

Vaksinasi terhadap penyakit ini belum ditemukan sehingga pengendalian vektor merupakan langkah penting yang dapat dilakukan untuk mencegah penularan penyakit ini. Pengendalian vektor yang panyak di gunakan saat ini adalah menggunakan insektisida sintetik. Penggunaan insektisida sintetik dapat mengganggu populasi non target, tetapi juga dapat mengakibatkan resistensi terhadap vector (Wattal et al., 1981)
Pengendalian vektor menggunakan bahan alam saat ini menjadi alternatif yang menguntungkan karena ramah lingkungan, mudah didegradasi dan tidak membunuh populasi non target (Redwane et al., 2002). Daun kemangi (Ocimum sanctum Linn) memiliki aroma wangi yang khas, rasanya agak manis dan dingin. Aroma khasnya berasal dari kandungan sitral yang tinggi pada daun dan bunganya. Tanaman ini dapat tumbuh baik di daerah yang beriklim tropis dan tingginya dapat mencapai 1,5 meter, daun berwarna hijau,dan bunganya tersusun dalam tandan tegak. Kemangi hidup liar di tempat kering yang mendapat sinar matahari (Agusta 2000).

Daun kemangi dapat berisifat sebagai larvasida pada nyamuk Anopheles maculatus dan Aedes aegypti (Lestari, 2010 \& Jumitawati, 2007). Aktifitas larvasida diduga oleh senyawa flavonoid, saponin, daneugenol. Flavonoid berfungsi sebagai 
racun pernapasan, saponin sebagai racun perut dan racun kontak, serta eugenol yang berperan dalam denaturasi protein sitoplasmik dan nekrosis jaringan (Soedarsono, 2002).

Senyawa saponin adalah suatu senyawa yang larut dalam pelarut organik dan air(Chapagain \& Wiesman, 2005). Etanol adalah pelarut yang mampu melarutkan senyawa saponin sehingga penelitian ini bertujuan untuk mengetahui efek ekstrak etanol daun kemangi sebagai larvisida nabati terhadap larva $C$. quinque fasciatus.

\section{METODE PENELITIAN}

Penelitian ini menggunakan larva $C$. Quinquefasciatus instar III yang diperoleh dari laboratorium Parasitologi FKUG Mada Yogyakarta. Besar sampel setiap perlakuan adalah 25 ekor dengan tiga kali replikasi.

Daun kemangi diperoleh dari petani Silok, Bantul dan determinasi tanaman dilakukan di laboratorium Biologi Farmasi Fakultas MIPA UII Yogyakarta. Daun kemang diekstrak dengan metode maserasi dengan bahan pelarut etanol 96\%. Variasi konsentrasi uji ekstrak yang diperoleh dari hasil uji pendahuluan yaitu 5000 ppm, 4500 ppm, 4000 ppm, 3500 ppm, 3000 ppm, 2000 ppm, 1500 ppm, 1000 ppm, dengan kontrol menggunakan Tween $0,25 \%$ dalam aquadest..

Dua puluh lima larva instar III dimasukkan dalam kontainer yang berisi $100 \mathrm{ml}$ ekstrak konsentrasi uji. Larva instar III dipaparkan dengan ekstrak selama 24 jam kemudian dihitung jumlah larva yang mati. Data kematian larva kemudian diolah dengan probit untuk mengetahui nilai LC50 dan LC90 dan dilanjutkan dengan menggunakan analisis uji Kruskal-Wallis.

\section{HASIL DAN PEMBAHASAN}

Data hasil uji larvasida ekstrak etanol daun kemangi dapat dilihat pada Tabel.1 dan Grafik.1.

Tabel 1. Persentase kematian larva instar III Culex quinquefasciatus yang dipapar dengan ekstrak etanol 96\% daun kemangi (Ocimum sanctum Linn) setelah 24 jam pada penelitian akhir.

\begin{tabular}{|c|c|c|c|c|c|c|}
\hline \multirow{2}{*}{ Konsentrasi (ppm) } & \multirow{2}{*}{ Jumlah Larva Uji } & \multicolumn{4}{|c|}{ Mortalitas } & \multirow{2}{*}{$\begin{array}{c}\text { Persentase Kumulatif } \\
\text { Mortalitas }\end{array}$} \\
\hline & & I & II & III & Rerata & \\
\hline 5000 & 25 & 25 & 24 & 25 & 24,6 & $98,4 \%$ \\
\hline 4500 & 25 & 22 & 19 & 24 & 21,6 & $86,4 \%$ \\
\hline 4000 & 25 & 19 & 21 & 24 & 21,3 & $85,2 \%$ \\
\hline 3500 & 25 & 13 & 15 & 15 & 14,3 & $57,2 \%$ \\
\hline 3000 & 25 & 15 & 14 & 14 & 14,3 & $57,2 \%$ \\
\hline 2000 & 25 & 20 & 9 & 12 & 13,6 & $54,4 \%$ \\
\hline 1500 & 25 & 11 & 2 & 7 & 6,6 & $26,4 \%$ \\
\hline 1000 & 25 & 3 & 1 & 2 & 2 & $8 \%$ \\
\hline Kontrol & 25 & 0 & 0 & 0 & 0 & $0 \%$ \\
\hline
\end{tabular}

Kelompok kontrol memiliki perbedaan efek yang signifikan dengan semua konsentrasi ekstrak dilihat dari nilai $\mathrm{p}$ yang kurang dari 0,05 . Perbedaan yang signifikan antara kontrol dengan semua variasi ekstrak menunjukkan bahwa semua variasi konsentrasi ekstrak etanol $96 \%$ daun kemangi (Ocimum sanctum Linn) efektif dalam membunuh larva instar III Culex quinquefasciatus.

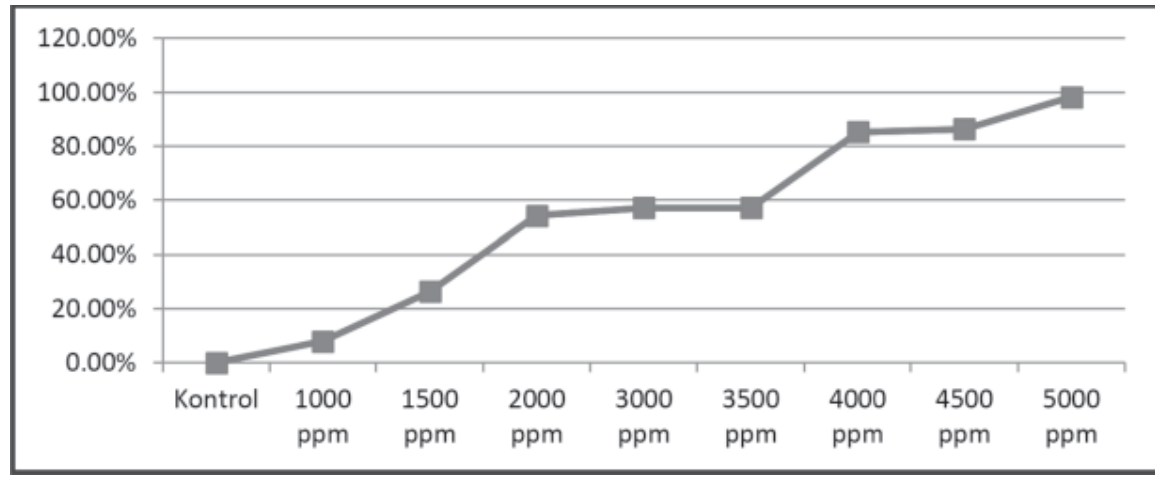

Grafik 1. Persentase kematian larva instar III Culex quinquefasciatus dari kelompok kontrol dan kelompok perlakuan dengan berbagai konsentrasi. 
Data hasil uji larvasida ekstrak etanol daun kemangi menunjukkan distribusi dan data yang tidak homogen sehingga dilanjutkan dengan uji Kruskal wallis. Uji Kruskals-Wallis diperoleh nilai $\mathrm{p}=0,005$. Hal ini menujukkan bahwa terdapat perbedaan persentase kematian larva C. Quingquefasciatus. Uji Mann-Whitney dilanjutkan untuk mengetahui perbedaan antar masing kelompok.
Konsentrasi yang paling efektif dalam membunuh larva Culex quinquefasciatus adalah pada konsentrasi 5000 ppm yaitu sebesar 98,4\% meskipun secara statistik tidak berbeda signifikan dengan konsentrasi lainnya.Antara konsentrasi 1000 ppm dengan konsentrasi lainnya terdapat perbedaan yang signifikan pada hampir semua variasi konsentrasi ekstrak kecuali pada konsentrasi $1500 \mathrm{ppm}$, yaitu nilai p labih dari 0,05 (Tabel 2)

Tabel 2. Uji Mann-Witney terhadap presentase kematian larva instar III Culex quinquefasciatus pada berbagai konsentrasi ekstrak etanol 96\% daun kemangi (Ocimum sanctum Linn).

\begin{tabular}{cccccccccc}
\hline & $5000 \mathrm{ppm}$ & $4500 \mathrm{ppm}$ & $4000 \mathrm{ppm}$ & $3500 \mathrm{ppm}$ & $3000 \mathrm{ppm}$ & $2000 \mathrm{ppm}$ & $1500 \mathrm{ppm}$ & $1000 \mathrm{ppm}$ & kontrol \\
\hline $5000 \mathrm{ppm}$ & & 0,072 & 0,072 & 0,043 & 0,043 & 0,046 & 0,046 & 0,046 & 0,034 \\
$4500 \mathrm{ppm}$ & 0,072 & & 0,822 & 0,046 & 0,046 & 0,127 & 0,050 & 0,050 & 0,037 \\
$4000 \mathrm{ppm}$ & 0,072 & 0,822 & & 0,046 & 0,046 & 0,127 & 0,050 & 0,050 & 0,037 \\
$3500 \mathrm{ppm}$ & 0,043 & 0,046 & 0,046 & & 0,814 & 0,507 & 0,046 & 0,046 & 0,034 \\
$3000 \mathrm{ppm}$ & 0,043 & 0,046 & 0,046 & 0,814 & & 0,507 & 0,046 & 0,046 & 0,034 \\
$2000 \mathrm{ppm}$ & 0,046 & 0,127 & 0,127 & 0,507 & 0,507 & & 0,127 & 0,050 & 0,037 \\
$1500 \mathrm{ppm}$ & 0,046 & 0,050 & 0,050 & 0,046 & 0,046 & 0,127 & & 0,814 & 0,037 \\
$1000 \mathrm{ppm}$ & 0,046 & 0,050 & 0,050 & 0,046 & 0,046 & 0,050 & 0,184 & & 0,037 \\
kontrol & 0,034 & 0,037 & 0,037 & 0,034 & 0,034 & 0,037 & 0,037 & 0,037 & \\
\hline
\end{tabular}

Tabel 3. Hasil analisis probit efek larvisidal ekstrak etanol 96\% daun kemangi (Ocimum sanctum Linn) terhadap larva instar III Culex quinquefasciatus.

\begin{tabular}{cccc}
\hline$\%$ mortalitas & LCx & \multicolumn{2}{c}{ Kisaran batas } \\
$(\mathrm{x})$ & $(\mathrm{ppm})$ & Bawah & Atas \\
10 & 1038,055 & 741,3769 & 1453,455 \\
\cline { 2 - 3 } 20 & 1360,581 & 1045,4 & 1770,789 \\
30 & 1653,675 & 1331,81 & 2053,325 \\
40 & 1953,423 & 1626,404 & 2346,192 \\
50 & 2281,931 & 1941,23 & 2682,425 \\
60 & 2665,686 & 2286,559 & 3107,675 \\
70 & 3148,871 & 2679,331 & 3700,693 \\
90 & 3827,191 & 3165,191 & 4627,649 \\
\end{tabular}

Analisis probit ekstrak etanol $96 \%$ daun kemangi (Ocimum sanctum Linn) menunjukkan memiliki LC50 2281,931 ppm dan LC90 5016,314 ppm.

Penemuan insektisida yang ramah lingkungan sangat penting. Insektisida yang digunakan diharapkan aman dan tidak dibuat dari bahan sintetik. Hal ini didapatkan dari tanaman yang didalamnya terdapat senyawa fitokimia yang dapat bersifat sebagai insektisida (Gautam, 2013). Daun kemangi memiliki kandungan senyawa flavonoid, saponin, dan eugenol.

Pengamatan secara mikroskopik pada larva yang diberi ekstrak flavonoid dari tanaman V.negundo menunjukkan gambaran disintegrasi integumen yang dikaitkan dengan hilangnya lapisan kitin dan peregangan abnormal tubuh larva. Hal ini diduga karena efek neurotoksik ekstrak flavonoid (Gautam, 2013).

Senyawa saponin dapat bersifat sebagai insektisida adalah dengan merubah perilaku makannya yaitu dengan cara menghambat uptake makanan pada saluran pencernaan. Saponin juga dapat menghambat pertumbuhan stadium larva dengan menganggu tahap moulting larva (Chaieb, 2010). Saponin dapat menyebabkan perubahan pada permeabilitas membran dan menyebabkan disorganisasi molecular (Chaieb, 2007).

Eugenol yang dikenal dengan nama allyl guaiacol bekerja dengan menghambat oksidasi flavin-Linked \& NAD-linked substrates menyebabkan denaturasi protein sitoplasmik dan nekrosis jaringan (Agusta, 2000). 


\section{SIMPULAN}

Ekstrak etanol daun kemangi (ocimumsanctum linn) mempunyai efek larvasida terhadap larva instar iii culexquinquefasciatus

\section{DAFTAR PUSTAKA}

Agusta, A., 2000. MinyakAtsiriTumbuhanTropika Indonesia. ITB, Bandung.

Agusta, A., 2000. MinyakAtsiriTumbuhanTropika Indonesia. ITB, Bandung.

Chaieb I, Trabelesi M, Ben Halima-Kamel M, Ben Hamouda MH. Histological effects of Cestrum parqui saponin on Schistocercagregaria and spodoptera littoralis.2007.J.Biol.Sci.7:95-101

Chaieb I. Saponin as insecticide : a review. 2010. Tunisian.J.of plant. Protection.5:39-50.

Chapagain B, Wiesman Z. Larvacidal effects of aqueus extract of Balanites aegyptica (desert date) againts the larvae of Culex pipiens. 2005. Afr.J.Biotechnology. 4(11):1351-1354.

El Hag EA, Nadi AH, Zaitoon AA. Toxic and growth retarding effects of there plant extract on Culex pipiens larvae (Diptera: Culicidae). 1999. Phytother.Res.13:388-392.

Gautam K, Kumar P, Poonia S. Larvacidal activity and GC-MS analysis of lavonoids of Vitex negundo and Andrographics paniculata againts two vector mosquitoes Anopheles stephensi and Aedes aegypti. 2013. J.Vector. Borne.Dis.50.171-178.

Juwitawati, V.D., 2007, Uji Toksisitas Minyak Atsiri dari Daun Ocimum sanctum Linn(Kemangi) terhadap Larva Aedesaegypti, Skripsi, jurusan Kedokteran Umum Fakultas Kedokteran, UniversitasGadjahMada.

Lestari, E., 2010, Efektivitas Ekstrak Daun Kemangi terhadap Larva Instar III Anopheles maculatus, Skripsi, Jurusan Pendidikan Dokter Fakultas Kedokteran, Universitas Islam Indonesia.

Redwane A, Lazrek HB, Bouallam S, Markouk M, Amarouch H, Jana M. Larvacidal activity of extract from Querus lusitania var infectoria galls (oliv). 2002.

Soedarsono, Gunawan, D., Wahyuono, S., Donatus, I.A., Purnomo. TumbuhanObat II (Hasil Penelitian, Sifat-sifat, danPenggunaan).2002.Pusat Studi Tradisional Universitas Gadjah Mada, Yogyakarta.

Wattal BL, Joshi GC, Das M. Role of agricultural insecticides in precipitation vector resistance. 1981. J.Comm.Dis.13:71-73.

Zulkoni, A., 2010. Parasitologi, Nusa Medika, Yogyakarta. 